\title{
Notes on Transcription and Transliteration
}

I have used two transliteration systems to represent standard Arabic (SA) and colloquial Egyptian Arabic (EA):

I. Written sources in standard literary Arabic are cited according to the International Journal of Middle East Studies (IJMES) transliteration system with the additional underlining of bigraphic symbols that reflect a single phoneme ( $\mathrm{kh}$, rather than $\mathrm{kh}$ as in IJMES, for example, so that the latter is not left undifferentiated from the sequential occurrence of $\mathrm{k}$ and $\mathrm{h}$ ). Standard Arabic forms of some colloquial lexical items have been adopted in the English passages of the text with minimal diacritic markings (thus, throughout the English text, Banī Hilāl, Shaykh, and Abū Zayd rather than Benī Hilāl, shaykh, Abū Zēd or Zeyd, etc.). In addition, a number of the most commonly recurring place-names such as al-Bakātūsh and Kafr al-Shaykh are left without diacritics in the English text. Transliterations have not been used for proper names and terms that have accepted English forms such as Mecca, Islam, and Sufi.

2. In transliterating colloquial Egyptian dialect, I have adopted the basics of the IJMES transcription system with the addition of several vowels to accommodate Egyptian.colloquial Arabic forms:

$$
\begin{array}{llll}
\mathrm{a} & \overline{\mathrm{a}} & {[\mathrm{ay}]} & \grave{\mathrm{a}}=\text { alif maqșūa in SA transliteration } \\
\mathrm{i} & \overline{1} & \\
\mathrm{e} & \overline{\mathrm{e}} & {[\mathrm{ey}]} \\
\mathrm{o} & \overline{\mathrm{o}} & \\
\mathrm{u} & \overline{\mathrm{u}} & {[\mathrm{aw}]}
\end{array}
$$

In addition, certain modifications have been adopted for transliterating Egyptian colloquial Arabic consonants in order to preserve key features that mark code-shifting between colloquial Arabic, "elevated" colloquial, and standard Arabic, a process common in Sìrat Banī Hilāl perfor- 
mances. This modified system represents an attempt to provide a broadly phonemic transcription of colloquial texts in a manner that reflects both the occurrence of significant phonological shifts and the commonly understood cognate standard Arabic forms.

\begin{tabular}{|c|c|c|c|}
\hline 1 & , & $b$ & $\mathrm{t}$ \\
\hline ب & b & b & $\mathrm{z}[\underline{\mathrm{TH}}]^{1}$ \\
\hline$=$ & $t$ & $\varepsilon$ & c \\
\hline$ث$ & $\mathrm{~s}[\underline{\mathrm{th}}]^{1}$ & $\varepsilon$ & $\underline{\mathrm{gh}}$ \\
\hline ع & $\mathrm{j} / \mathrm{g}^{4}$ & ف & f \\
\hline$\tau$ & ha & ن & $Q / q^{3} / q^{4}$ \\
\hline$\dot{\tau}$ & $\underline{\mathrm{kh}}$ & كل & $\mathrm{k}$ \\
\hline s & d & J & 1 \\
\hline j & $\mathrm{z}[\underline{\mathrm{dh}}]^{1}$ & $r$ & $\mathrm{~m}$ \\
\hline , & $r$ & ن & $\mathrm{n}$ \\
\hline j & z & - & $\mathrm{h}$ \\
\hline س & $\mathbf{s}$ & , & w \\
\hline ش & $\underline{\text { hh }}$ & ي & $\mathrm{y}$ \\
\hline ص & ș & : & $\mathrm{a} / \mathrm{at}{ }^{2}$ \\
\hline ض & d & ال- & $\mathrm{al}-_{-}^{3}$ \\
\hline
\end{tabular}

For Arab scholars who have published in languages other than Arabic, I have, for the most part, both cited their chosen spelling in European languages and provided a transliteration of the original Arabic form.

I. The bracketed standard Arabic allophones are transcribed as such where they occur in the texts.

2. -at form in construct state.

3. The definite article has been transcribed in the body of the text (al-) as per IJMES, without assimilation, except in direct quotations from actual performances: thus al-shams rather than ish-shams in the body of the text, but al-, il-, el-, and ul- with assimilation where it occurs, in quotations from performances.

4. The local dialect of al-Bakātūsh, and Sìrat Banī Hiläl texts in general in this region, makes use of $j / g$ alternation for the phoneme [ $?$ ] as well as three forms of the phoneme [ $]$ ]: /q/, /glottal stop/, and $/ g /$, which have been rendered as follows:

$\mathrm{Q}=/ q /$, voiceless uvular stop, as in standard Arabic al-Qähira 'Cairo'

$\mathrm{q}^{\prime}=13 /$, glottal stop, as in the Cairene pronunciation of 'âl li 'he said to me'

$\mathrm{q}=/ \mathrm{g} /$, voiced velar stop, as in Upper Egyptian dialect galli 'he said to me'

Since the latter form is by far the most common in texts from this region, this system has the advantage of leaving most occurrences of the phoneme unmarked, while distinguishing only the less common, variant allophones. N.B. In these transcriptions, $q$ and $g$ represent the same spoken sound, though they reflect two distinct Standard Arabic phonemes.

In addition, numerous forms occur in Sìrat Bani Hiläl performances from the region of alBakātūsh which appear to reflect case endings similar to those of standard written Arabic; these have been superscripted: ruht-I biläd' tirkab il-afyāl 'I have gone to countries where elephants are ridden'. 
HEROIC POETS, POETIC HEROES 
